\title{
Parasite infracommunities of Leporinus friderici: A comparison of three tributaries of the Jurumirim Reservoir in southeastern Brazil
}

\author{
FÁBIO H. YAMADA, MARCELA F. BONGIOVANI, PRISCILLA O.F. YAMADA and REINALDO J. DA SILVA
}

São Paulo State University/Unesp, Institute of Biosciences, 18618-689 Botucatu, SP, Brazil

Manuscript received on August 29, 2016; accepted for publication on October 28, 2016

\begin{abstract}
The degradation and homogenization of natural habitats is considered a major cause of biotic homogenization. Many studies have been undertaken on the effects of dams on aquatic wildlife, in particular fish assemblages. But how do dams affect the parasitic fauna of such fish? The aim of the present study was to examine parasitic similarity, comparing the diversity and structure of parasite communities of Leporinus friderici (Characiformes, Anostomidae) in three upstream tributaries under the influence of the Jurumirim Dam on the Upper Paranapanema River in southeastern Brazil. The present study did not find any significant differences in parasite communities among populations of $L$. friderici in the three upstream tributaries. This result highlights that dams promote and facilitate the dispersal of organisms between localities, and therefore the spatial homogenization of parasite communities. Overall, the results suggest that fish parasite assemblages can provide suitable data for evaluating biotic homogenization caused by dams.
\end{abstract}

Key words: Neotropical region, Leporinus friderici, metazoan parasites, similarity, watershed conservation.

\section{INTRODUCTION}

Intermediate disturbance frequencies and/or intensities and other environmental fluctuations can maintain biological diversity by reducing the dominance of some species and so can shape evolutionary and ecological processes in aquatic and terrestrial ecosystems (Wilson 1990, Poff et al. 2007, Rahel 2010). Unfortunately, with increasing worldwide demand for water and electricity, dam construction is inevitable and results in simplified

Correspondence to: Fábio Hideki Yamada

E-mail: fhyamada@hotmail.com natural landscapes, homogenizing the regional distinctiveness of natural disturbance dynamics (Rahel 2002, Olden et al. 2004, Morley 2007, Rahel 2010). This anthropogenic activity can be considered the more extensive alteration in riverine ecosystems (Nilsson et al. 2005). Lees et al. (2016) highlighted an extensive list of dam impacts such as favoring generalist or invasive species, loss of beta diversity, inhibiting both downriver sediment flow and up and downstream organismal migration, loss of endemic species, habitat fragmentation, economic losses in local fisheries, etc. 
Biotic homogenization is the increased similarity of biotas over time that integrates many aspects of the biodiversity crisis such as species introduction, extirpation, and habitat alteration (Mckinney and Lockwood 1999). Dam interventions leads to the decline of many species that are replaced by a much smaller number of expanding species that thrive in environments altered by humans (Olden and Rooney 2006, Rahel 2007). Endemic species are replaced by cosmopolitan species with the result that entire ecosystems come to resemble each other (Rahel 2002, Scott 2006).

Dams are classic examples of human interventions in natural flow regimes that cause changes in the ecology of freshwater organisms by reducing natural regional differences and thus imposing environmental homogeneity on a large geographic scale (Poff et al. 2007). In Brazil, the Upper Paraná River basin has suffered intense and dramatic damming since 1901, with the construction of more than 145 large dams that correspond to almost $50 \%$ of the total impounded area (Agostinho et al. 2008). The Paranapanema River is one of the most important tributaries of the Paraná River. The Jurumirim dam was built in the late 1950s and is the first of 11 cascading dams along the main course of the Paranapanema River (Nogueira et al. 2006). Cascades of dams have been constructed on the main rivers of southeastern Brazil, altering the up- and downstream connections of the dam (Arcifa and Esguícero 2012), and producing a discontinuity along the longitudinal gradient (Gumiero and Salmoiraghi 1998).

Parasites have undergone serious changes in composition and structure due to human activity that influences the functioning and stability of the ecosystem (Lafferty 1997, Lafferty and Kuris 1999). Fish parasite communities may respond directly or indirectly to such changes, due to their intimate contact with both the host and the aquatic environment (Kadlec et al. 2003). Dams modify the water level regime and current velocity, which affects the distribution of aquatic vegetation, icthyophagous birds, and the population density of invertebrates and fish (Morley 2007). Many studies have analyzed the consequences of dams for the parasite fauna of aquatic wildlife in temperate regions (Bauer and Stolyarov 1961, Dogiel 1958, Holloway and Hagstrom 1981, Mackie et al. 1983, Forstie and Holloway Jr 1984, Morley 2007). Karling et al. (2012) pointed out that the helminth fauna of a piscivourous fish suffered changes in richness and abundance after the construction of the Porto Primavera Reservoir, on the Paraná River, in southeastern Brazil. This study highlighted the disappearance of the digenean Prosthenhystera obesa after the establishment of a reservoir. In the studied area, the effects of the Jurumirim Dam have been well documented for phytoplankton (Henry et al. 2006), zooplankton (Casanova and Henry 2004), periphyton (Moschini-Carlos et al. 2000), benthic macroinvertebrates (Jorcin and Nogueira 2008), aquatic macrophytes (Costa and Henry 2010), and fishes (Carvalho et al. 2005, Kurchevski and Carvalho 2014). However, no data of the effects on the fish parasite community are available for this dam.

Leporinus friderici (Bloch, 1794) (Characiformes, Anostomidae) is a freshwater fish commonly called "piava" or "piau-três-pintas" widely distributed in South American countries (Suriname, Brazil, Paraguay, Argentina, and Uruguay) (Graça and Pavanelli 2007). Its migration is seasonal and short-distance (Agostinho et al. 2003) and it possesses ecological plasticity (Benedito-Cecilio et al. 2005). Studies have investigated the composition of the parasite fauna of this fish in Brazilian rivers (Feltran et al. 2004, Guidelli et al. 2006, Kohn et al. 2011), but none have assessed the effects of the dam on its parasitic fauna.

To date, most efforts to quantify faunal homogenization in freshwater ecosystems has 
focused on fish assemblages. However, how can dams affect the parasitic fauna of these fish? Considering the biotic homogenization effect of dams, the present study hypothesizes that the Jurumirim Dam homogenizes the parasitic fauna of L. friderici in three upstream tributaries. The aim of this paper was to examine the similarity, diversity and structure patterns of parasite communities of L. friderici in three upstream tributaries under the influence of the Jurumirim Dam. Fish parasites can have a positive role and are involved in most of the links of the food web and the flow of energy in aquatic ecosystems. Consequently, shifts in fish parasite composition in dammed rivers will change the state of productivity and sustainability of these ecosystems.

\section{MATERIALS AND METHODS}

STUDY AREA, FISH COLLECTION AND LABORATORY PROCEDURE

The Jurumirim Reservoir $\left(23^{\circ} 12^{\prime} 17^{\prime}\right.$ ' $\mathrm{S}$, $\left.49^{\circ} 13^{\prime} 19^{\prime \prime} \mathrm{W}\right)$ is the uppermost reservoir in a cascade system in the Paranapanema River, and is classified as oligotrophic (Henry et al. 2006). Samplings of hosts were carried out between April 2012 and June 2013 using gillnets of different mesh sizes and with standardized effort in three upstream tributaries under the influence of the Jurumirim Dam: the Taquari River $\left(23^{\circ} 29^{\prime} 21.95^{\prime}\right.$ 'S, $\left.49^{\circ} 12^{\prime} 6.90^{\prime \prime} \mathrm{W}\right)$, the Veados River $\left(23^{\circ} 15^{\prime} 42.4^{\prime}\right.$, $\left.48^{\circ} 37^{\prime} 27.6^{\prime \prime} \mathrm{W}\right)$ and the Paranapanema River (2315'11.9'S, 49¹2'34.2”W) (Figure 1). In total, 116 specimens of $L$. friderici were examined for metazoan parasites, as follows: 34 specimens from the Paranapanema River (PR) with a length ranging from 8.9 to $24 \mathrm{~cm}$ with a median length of $18.49 \pm 4.84(\mathrm{SD}) \mathrm{cm} ; 36$ specimens from the Taquari River (TR) with length ranging from 9.3 to $25 \mathrm{~cm}$ with a median length of $18.73 \pm 5.28$ (SD) $\mathrm{cm}$; and 46 from the Veados River (VR) with a length ranging from 9 to $27 \mathrm{~cm}$ with a median length of $14.59 \pm 5.79(\mathrm{SD}) \mathrm{cm}$. The captures were authorized by the Department of Fishing Promotion and Inspection/DEFOP (License \#SP/538/88). All animal procedures were performed in full compliance with the Ethics Committee for Animal Experimentation /CEEA (protocol \#120) of the Universidade Estadual Paulista/UNESP.

The collection, preservation and preparation of the parasites were conducted based on the methodology compiled by Eiras et al. (2006). The identification of the parasite taxa was performed using Moravec (1998), Thatcher (2006), and Cohen et al. (2013).

\section{STATISTICAL ANALYSES}

Statistical analyses were performed at community level (i.e., all helminths of all fish collected per site) and infracommunity (i.e., all the helminths of each individual host) component level. Prevalence and the mean intensity of infection/infestation were calculated for each parasite species in each host population in accordance with Bush et al. (1997). Comparison of the parasitized and non-parasitized hosts among the tributaries was performed using the $G$ test ( $2 \times 3$ contingency table) (Zar 2010). Comparisons of the intensity of infection/ infestation by each shared parasite species between the tributaries was performed using the KruskalWallis test (Zar 2010).

To describe the component community, the total number of species of parasite, the total number of individual parasites, the ShannonWiener index (H'), which gives equal weight to rare and abundant species, the Simpson index (1-D) which is sensitive to changes in the most abundant species composition, the Pielou evenness index (J), and the Berger-Parker index (BP), which evaluates uniformity among the component community were employed (Magurran 2004). The spatial turnover in the component community structure between tributaries was evaluated calculating Whittaker's 
$\beta$-diversity index (Whittaker 1960). Statistical differences in infracommunity diversity (ShannonWiener index) among host populations from the three tributaries were tested using the KruskalWallis test (Zar 2010). The EstimateS program was used to estimate parasite species richness for each host population (see Colwell and Coddington 1994).

Component communities were compared qualitatively (i.e. by parasite species composition) within the locality using the Jaccard index and quantitatively (i.e. by species abundance) using the Bray-Curtis index (Magurran 2004). An analysis of similarity (ANOSIM) using the Jaccard index (qualitative) and the Bray-Curtis index (quantitative) was performed with 10,000 permutations to test the null hypothesis of no difference in the composition and abundance of the parasite community of $L$. friderici among three tributaries using PAST software (Hammer et al. 2001).

Based on an assumption that the TR host population (see Figure 1) is further away from the other rivers, a Mantel test (with 9999 randomization runs) was performed using PC-ORD 5.0 (McCune and Mefford 1999) to determine the association between infracommunity similarity (Bray-Curtis index) and geographic distance $(\mathrm{km})$ matrices.

Parasite abundance data was transformed $\left\{\log _{10}(\mathrm{x}+1)\right\}$ and discriminant function analysis (DFA), based on Mahalanobis distances, was performed to evaluate differences between the parasite community composition of $L$. friderici from three sampled areas. Only parasite species with prevalence higher than $5 \%$ in at least one locality were considered in discriminant function analysis. This analysis was performed using Statistica software version 7.1 (Statsoft Inc. 2005).

\section{RESULTS}

A total of 808 metazoan parasites were recovered, 90 in PR with (mean abundance \pm SE) $2.64 \pm 0.77$ parasites/fish (range $1-23$ ); 419 in TR (mean abundance \pm SE) $11.63 \pm 4.56$ parasites/fish (range 1 - 148); and 299 in VR (mean abundance \pm SE) $6.5 \pm 1.87$ parasites/fish (range $1-70$ ). In all, 14 parasite taxa were recorded in the host population of $L$. friderici from three tributaries (nine in PR, 11 in VR and 13 in TR). Among these, Monogenea was the most diverse and prevalent taxonomic group from all the sampled areas. Eight parasite species were shared among the tributaries (Table I). Most hosts were parasitized by one species (Figure 2).

Eight taxa were shared among the host populations, six Monogenea (Dactylogyridae gen. sp. 1, Jainus piava, Jainus sp., Tereancistrum sp., Urocleidoides sp. 1, and Urocleidoides sp. 2) and two Nematoda (P. (Spirocamallanus) amarali and $P$. (Spirocamallanus) iheringi). No differences were observed in the prevalence of these $\operatorname{tax} a(\mathrm{G}-$ test, $\mathrm{p}>0.05$ ) (Figure 3 ). In addition, we did not detect any differences in the intensity of infection/ infestation among the shared parasite species (Kruskall-Wallis test, $\mathrm{p}>0.05$ ).

The parasite community of the host population from PR had the highest mean diversity index (Shannon-Wiener and Simpson's index) and, consequently, high distribution uniformity of parasite abundance (Pielou index) (Table II). Furthermore, there were no statistically significant differences between parasite diversities (KruskallWallis test, $\mathrm{H}=1.151 ; \mathrm{p}=0.478$ ).

Estimators of species richness provided roughly similar results with the observed values exhibiting a satisfactory level of sampling effort (Figure 4).

The parasite communities displayed a low species turnover rate between tributaries $(20 \%$ pairwise PR vs VR, 18\% pairwise PR vs TR, and 


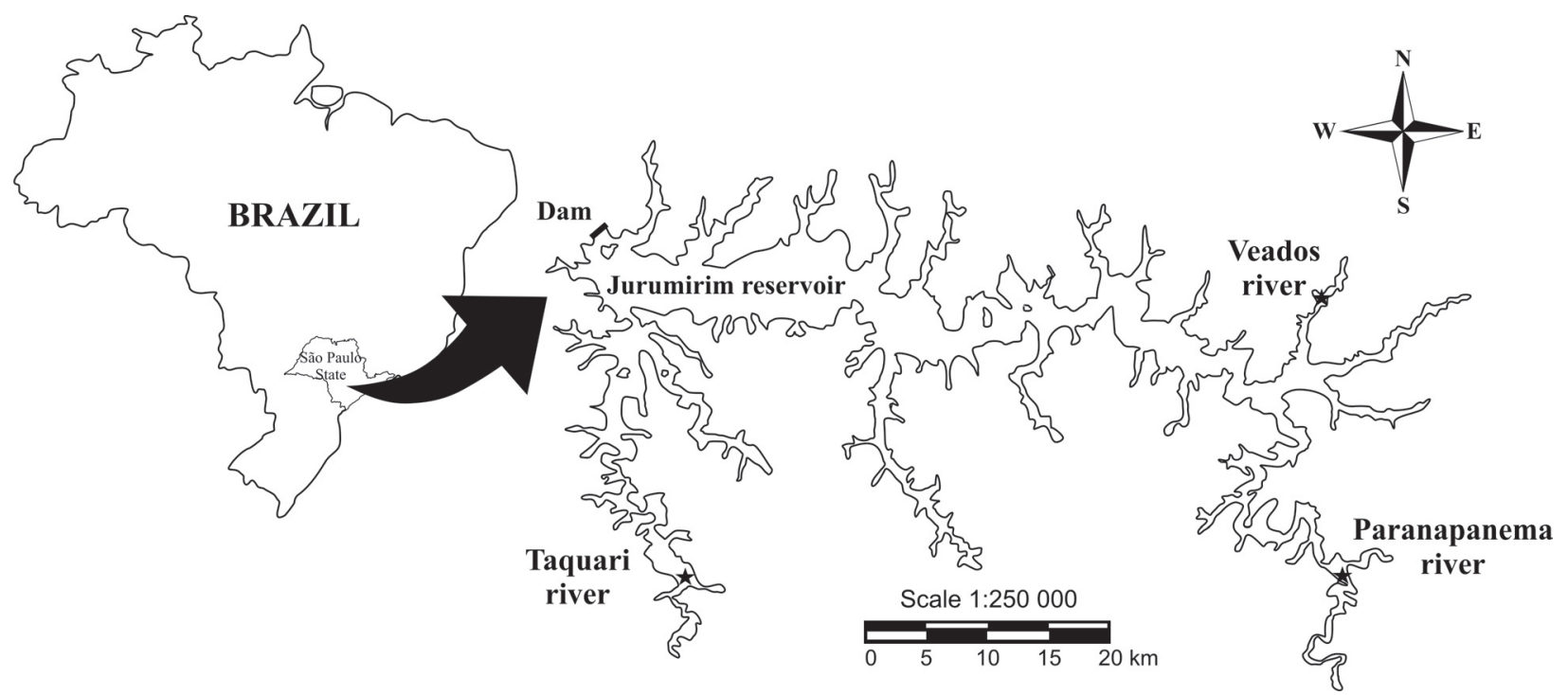

Figure 1 - The Jurumirim reservoir with the marked sampling site (stars), Upper Paranapanema River, São Paulo State, Brazil.

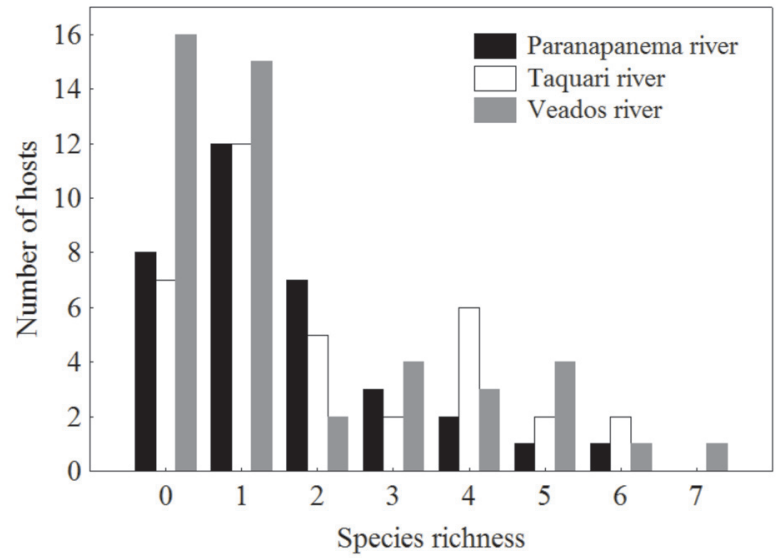

Figure 2 - Distribution of species richness in the parasite infracommunities of Leporinus friderici from three upstream tributaries of Jurumirim reservoir, Upper Paranapanema River, southeast, Brazil.

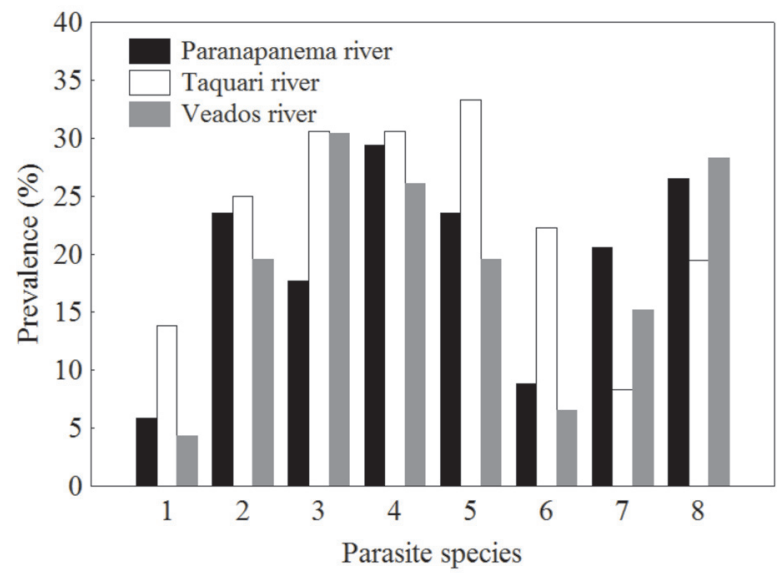

Figure 3 - Prevalence of eight parasite species shared by Leporinus friderici populations in three upstream tributaries of Jurumirim reservoir, Upper Paranapanema River, southeast, Brazil. (1 = Dactylogyridae gen. sp. 1; 2 = Jainus piava; 3 = Jainus sp.; $4=$ Tereancistrum sp.; 5 $=$ Urocleidoides sp. 1; $6=$ Urocleidoides sp. $2 ; 7=P .(S$. amarali; $8=$ P.(S.) iheringi). 

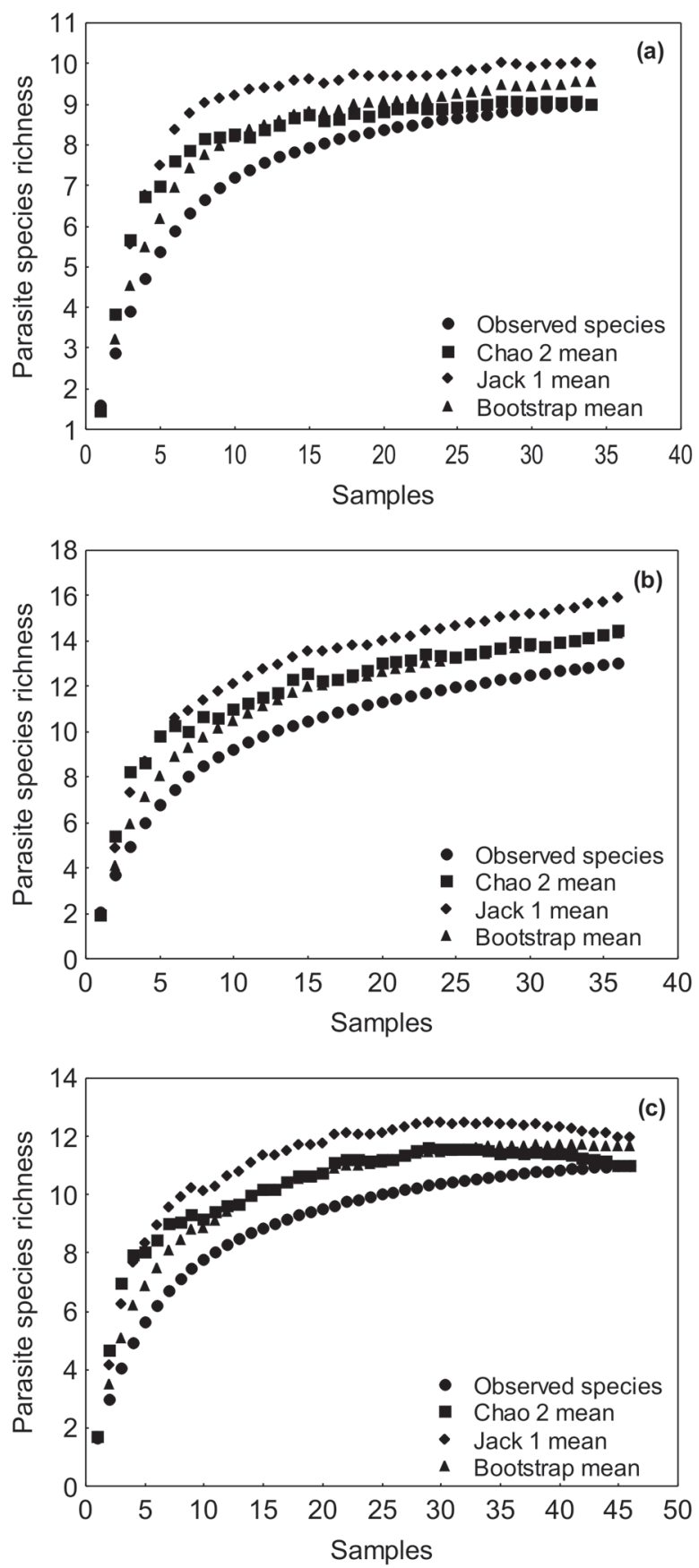

Figure 4 - Species accumulation curves of parasite component community for three populations of Leporinus friderici from upstream tributaries of Jurumirim reservoir, Upper Paranapanema River, southeast, Brazil. (a) Paranapanema, (b) Taquari, and (c) Veados rivers.
17\% pairwise TR $v s$ VR), and therefore a high degree of similarity. Similarity within component communities of host populations exhibited qualitative and quantitative homogeneity (Table III). Furthermore, ANOSIM did not detect any spatial difference in the composition and abundance of parasite species among between host populations $\left(\mathrm{R}_{\text {Jaccard }}=-0.005 ; \mathrm{p}=0.645 ; \mathrm{R}_{\text {Bray-Curtis }}=0.012 ; \mathrm{p}=\right.$ 0.189 ).

There was not relationship or association between parasite infracommunity similarity and the geographic distance matrices (Mantel test, $r=$ 0.017; $p=0.185)$. Furthermore, DFA did not present significant differences between infracommunities and failed to reject the null hypothesis of equality between the mean vectors of the infracommunities (Wilks's $\lambda=0.745 ; \mathrm{F}_{22,206}=1.477 ; \mathrm{p}<0.084$ ).

\section{DISCUSSION}

The worldwide demand for water and power generation has dramatically increased the risks for freshwater ecosystems. For this purpose, more reservoirs have been built in recent years, raising concern over biological conservation. Dams usually affect the ecological and evolutionary processes of resident biota by modifying and replacing the function and diversity of river habitats (Poff et al. 2007). In addition, these impacts on landscape structure change the natural disturbance regime of the river and, are usually described as one of the major reasons for freshwater biotic homogenization (Mckinney 2006). Vagility is an important host trait that influences the structure and composition of parasite communities from different locations. In the present study we recognized that the Jurumirim Reservoir performs as a mediator, facilitating the spread of both host populations and disease. Thus, parasites can have a colonizing ability independent of the vagility of the fish host, a fact that increases similarity among communities. Therefore, the levels of parasitism observed among populations 
TABLE I

Parasite component community of Leporinus friderici from three upstream tributaries of Jurumirim reservoir, Upper Paranapanema River, southeast, Brazil. Paranapanema River (PR), Taquari River (TR), Veados River (VR), prevalence $(\mathrm{P} \%)$, mean intensity (MI) \pm standard error (SE), and site of infection/infestation (SI).

\begin{tabular}{|c|c|c|c|c|c|c|c|}
\hline \multirow{2}{*}{ Parasite species } & \multicolumn{2}{|c|}{ PR $(\mathbf{N}=34)$} & \multicolumn{2}{|c|}{$\mathrm{TR}(\mathrm{N}=\mathbf{3 6})$} & \multicolumn{2}{|c|}{$\operatorname{VR}(\mathrm{N}=46)$} & \multirow{2}{*}{ SI } \\
\hline & $\mathbf{P}(\%)$ & $\mathbf{M I} \pm \mathbf{S E}$ & $\mathbf{P}(\%)$ & $\mathbf{M I} \pm \mathbf{S E}$ & $\mathbf{P}(\%)$ & $\mathbf{M I} \pm \mathbf{S E}$ & \\
\hline \multicolumn{8}{|l|}{ Monogenea } \\
\hline Dactylogyridae gen. sp. 1 & 5.88 & 1 & 13.88 & $1.20 \pm 0.20$ & 4.34 & $1.5 \pm 0.5$ & Gills \\
\hline Dactylogyridae gen. sp. 2 & - & - & - & - & 4.34 & $4 \pm 2$ & Gills \\
\hline Jainus piava & 23.52 & $1.62 \pm 0.32$ & 25 & $7.88 \pm 2.36$ & 19.56 & $4 \pm 1.24$ & Gills \\
\hline Jainus sp. & 17.64 & $2.33 \pm 0.80$ & 30.55 & $5.36 \pm 2.19$ & 30.43 & $10.5 \pm 3.22$ & Gills \\
\hline Tereancistrum $\mathrm{sp.}$ & 29.41 & $1.4 \pm 0.16$ & 30.55 & $1.90 \pm 0.54$ & 26.08 & $2.16 \pm 0.6$ & Gills \\
\hline Urocleidoides sp. 1 & 23.52 & $2.87 \pm 1.25$ & 33.33 & $6.83 \pm 2.15$ & 19.56 & $2 \pm 0.22$ & Gills \\
\hline Urocleidoides sp. 2 & 8.82 & $1.33 \pm 0.33$ & 22.22 & $1.75 \pm 0.36$ & 6.52 & 1 & Gills \\
\hline \multicolumn{8}{|l|}{ Digenea } \\
\hline Metacercariae gen. sp. & 2.94 & 1 & 8.33 & $49 \pm 45.52$ & - & - & $\begin{array}{l}\text { Swim } \\
\text { bladder }\end{array}$ \\
\hline \multicolumn{8}{|l|}{ Nematoda } \\
\hline Contracaecum sp. & - & - & 2.77 & 1 & - & - & Intestine \\
\hline Procamallanus (Spirocamallanus) amarali & 20.58 & $1.28 \pm 0.28$ & 8.33 & $1.33 \pm 0.33$ & 15.21 & $2.28 \pm 0.51$ & Intestine \\
\hline Procamallanus (Spirocamallanus) iheringi & 26.47 & $1.11 \pm 0.11$ & 19.44 & $1.28 \pm 0.18$ & 28.26 & $1.61 \pm 0.24$ & Intestine \\
\hline Rhabdochona acuminata & - & - & 2.77 & 1 & 2.17 & 3 & Intestine \\
\hline Spinitectus asperus & - & - & 2.77 & 1 & - & - & Intestine \\
\hline \multicolumn{8}{|l|}{ Crustacea } \\
\hline Ergasilidae gen. sp. & - & - & 5.55 & $1.5 \pm 0.50$ & 8.69 & $2 \pm 0.7$ & Gills \\
\hline
\end{tabular}

of $L$. friderici reinforce the homogenization effects of dams on parasite communities.

More than just controlling river flow, damning a river simplifies the freshwater ecosystems and leads to conditions which change the parasite dynamic. In response to environmental stressors, fish parasite communities can increase or decrease prevalence, abundance and diversity (Lafferty and Kuris 1999). Bauer and Stolyarov (1961) noted a decline in the complete extirpation of many fish parasites (monogeneans, trematodes, nematodes, acanthocephalans, and crustaceans) during the establishment of a reservoir. Dams can favor parasites with direct life-cycles where all stages are completed on a single host (e.g. monogeneans). In the three studied areas, Monogenea was the most prevalent and abundant parasite. The loss of complex life-cycle parasite taxa (e.g. trematodes) can be the result of changing overall abiotic factors and, particularly, changes to the intermediate host community that lead to parasite homogenization. Previous studies have identified a significant reduction in potential intermediatehostcommunities (zooplankton and benthic communities), and thereafter a proportional decrease in fish density and diversity in the Jurumirim Reservoir (Henry et al. 1998, Mitsuka and Henry 2002). All these are key factors which maintain parasite dynamics. 
TABLE II

Estimates of infracommunity species richness and alpha diversity indexes of parasite community of Leporinus friderici from three upstream tributaries of Jurumirim reservoir, Upper Paranapanema River, southeast, Brazil. Paranapanema River (PR), Taquari River (TR), Veados River (VR).

\begin{tabular}{|c|c|c|c|}
\hline Estimator/Index & PR & TR & VR \\
\hline $\begin{array}{c}\text { Component } \\
\text { community } \\
\text { species richness }\end{array}$ & 9 & 13 & 11 \\
\hline $\begin{array}{l}\text { Component } \\
\text { community } \\
\text { abundance }\end{array}$ & 90 & 419 & 299 \\
\hline $\begin{array}{c}\text { Mean } \\
\text { infracommunity } \\
\text { species richness } \\
\pm \text { SD }\end{array}$ & $1.58 \pm 1.49$ & $2.05 \pm 1.82$ & $1.67 \pm 1.92$ \\
\hline $\begin{array}{c}\text { Mean } \\
\text { infracommunity } \\
\text { Shannon-Wienner } \\
\left(\mathrm{H}^{\prime}\right) \pm \mathrm{SD}\end{array}$ & $1.94 \pm 0.29$ & $1.79 \pm 0.23$ & $1.73 \pm 0.22$ \\
\hline $\begin{array}{l}\text { Simpson index } \\
\quad(1-D)\end{array}$ & 0.83 & 0.78 & 0.72 \\
\hline $\begin{array}{l}\text { Infracommunity } \\
\text { Pielou's evenness } \\
\quad(\mathrm{J}) \pm \text { SD }\end{array}$ & $0.39 \pm 0.48$ & $0.39 \pm 0.44$ & $0.25 \pm 0.38$ \\
\hline $\begin{array}{l}\text { Berger-Parker } \\
\text { index }\end{array}$ & 0.26 & 0.35 & 0.47 \\
\hline
\end{tabular}

TABLE III

Pairwise similarities index of parasite component community of Leporinus friderici from three upstream tributaries of Jurumirim reservoir, Upper Paranapanema River, southeast, Brazil.

\begin{tabular}{cccc}
\hline Pairwise & PR & TR & VR \\
\hline PR & - & 0.69 & 0.68 \\
TR & 0.32 & - & 0.71 \\
VR & 0.41 & 0.43 & - \\
& \multicolumn{3}{c}{ Bray-Curtis index } \\
\hline
\end{tabular}

A priori, similarities in parasite communities should decrease with increases in either the distinctness of the environments occupied or the geographical distance between any two host populations (Poulin and Morand 1999, Poulin
2003). Krasnov et al. (2012) point out that the environmental dissimilarity between host species populations are the best predictors of dissimilarity between parasite faunas. Quantitative differences in parasite infracommunities can indicate different host populations. Multivariate techniques such as canonical discriminant function can simultaneously analyze groups of parasites (Oliva and Ballón 2002). However, the present study did not find any distinct differences in parasite communities among populations of $L$. friderici from the three upstream tributaries. This result highlights that dams promote and facilitate the dispersal of organisms among localities, and therefore the spatial homogenization of parasite communities. Corroborating these results, a recent study found similarities in the levels of parasitism by metacercariae Sphincterodiplostomum musculosum Dubois, 1936, parasitizing Steindachnerina insculpta (FernandezYépez, 1948) in the same tributaries (Brandão et al. 2014).

The small pairwise regional differences in species composition (spatial turnover) may represent a homogenization of parasite faunas among tributaries under the influence of the Jurumirim dam. Many dams around the world have attenuated the seasonal and interannual streamflow variability of rivers, thereby causing biotic homogenization. These effects can diminish human wellbeing by decreasing the services that ecosystems can provide for people (Millennium Ecosystem Assessment 2005). One way to reduce biotic homogenization is to minimize habitat alteration, maintaining the periodicity of the reservoir water retention time, allowing a water flow level to be re-established in the river system. The permanently high water retention time (more than 180 days) and low degree of recurrent patterns have had a clear influence on the zooplankton community in the Jurumirim Reservoir (Sartori et al. 2009). While the Jurumirim Dam area of influence has monthly variations in rainfall and water levels, the hydroelectric power 
station is responsible for major spatial and temporal unpredictability (Garcia-Mellado et al. 2002, Nogueira et al. 1999, Kurchevski and Carvalho 2014). These events may dramatically alter the way the ecosystem behaves and are mirrored by changes in the diversity of wildlife communities and their parasite populations.

Unfortunately, freshwater ecosystems are undergoing abrupt ecological changes caused by increasing dam construction. Such changes include habitat loss and fragmentation, species loss, invasions, and homogenization. Despite these assumptions, the restoration of natural flows, removal of dams, and elimination of pollution can slow or even reverse the homogenization process (Rahel 2002, Rahel 2010). In the United States, more than 1000 obsolete dams have been removed and rivers reconnected over the last 40 years (O'Connor et al. 2015). Studies have also found that the rivers are resilient and their fish assemblages react quickly after dam removal (Hitt et al. 2012, Hogg et al. 2013, Gardner et al. 2013). Following this reasoning, what would happen to fish parasite assemblages after dam removal? These results should aid river managers and stakeholders in mitigating the negative effects of dams on the biotic homogenization process.

\section{ACKNOWLEDGMENTS}

The authors would like to thank the Fundação de Amparo à Pesquisa do Estado de São Paulo (FAPESP) (F.H.Y., \#2011/22603-3, 2014/142984), (M.F.B., \#2013/19776-9), (R.J.S., \# 2016/50377-1) and (P.O.F.Y., \#2013/25786-7); and the Conselho Nacional de Desenvolvimento Científico e Tecnológico (CNPq) (R.J.S., processo \# 307808/2014-9 and CNPq-PROTAX \# 440496/2015-2).

\section{REFERENCES}

AGOSTINHO AA, GOMES LC, SUZUKI HI AND JÚLIO JR HF. 2003. Migratory fishes of the Upper Paraná River Basin Brazil. In: Carolsfeld J et al. (Eds), Migratory fishes of South America: biology, fisheries and conservation status. Ottawa: World Fisheries Trust: The World Bank, Canada, p. 19-97.

AGOSTINHO AA, PELICICE FM AND GOMES LC. 2008. Dams and the fish fauna of the Neotropical Region: impacts and management related to diversity and fisheries. Braz J Biol 68: 1119-1132.

ARCIFA MS AND ESGUÍCERO ALH. 2012. The fish fauna in the fish passage at the Ourinhos Dam, Paranapanema River. Neotrop Ichthyol 10: 715-722.

BAUER ON AND STOLYAROV VP. 1961. The formation of parasite fauna and parasitic diseases of fish in water reservoirs. In: Dogiel VA et al. (Eds), Parasitology of fishes. Edinburgh: Oliver and Boyd, p. 246-254.

BENEDITO-CECILIO E, PEREIRA AL, BALERONI H AND FARIA ACEA. 2005. Effects of habitat on physiological indicators in Leporinus friderici (Pisces, Anostomidae) in the influence area of the Corumbá Reservoir, Goiás, Brazil. Acta Limnol Bras 17: 71-79.

BRANDÃO H, YAMADA FH, TOLEDO GM, ACOSTA AA, CARVALHO ED AND SILVA RJ. 2014. Parasitism by Sphincterodiplostomum musculosum (Digenea, Diplostomidae) metacercariae in the eyes of Steindachnerina insculpta (Characiformes, Curimatidae). Rev Bras Parasitol Vet 23: 144-149.

BUSH AO, LAFFERTY KD, LOTZ JM AND SHOSTAK AW. 1997. Parasitology meets ecology on its own terms: Margolis et al. revisited. J Parasitol 83: 575-583.

CARVALHO ED, MARCUS, LR, FOREST F AND SILVA VFB. 2005. Fish assemblage attributes in a small oxbow lake (Upper Paraná River Basin, São Paulo State, Brazil): species composition, diversity and ontogenetic stage. Acta Limnol Bras 17: 45-56.

CASANOVA SMC AND HENRY R. 2004. Longitudinal distribution of copepoda populations in the transition zone of Paranapanema river and Jurumirim reservoir (São Paulo, Brazil) and interchange with two lateral lakes. Braz J Biol 64: 11-26.

COHEN SC, JUSTO MCN AND KOHN A. 2013. South American Monogenoidea parasites of fishes, amphibians and reptiles. Rio de Janeiro: Oficina de Livros, 622 p.

COLWELL RK AND CODDINGTON JA. 1994. Estimating the extent of terrestrial biodiversity through extrapolation. Philos Trans R Soc Lond 345: 101-118.

COSTA MLR AND HENRY R. 2010. Phosphorus, nitrogen, and carbon contents of macrophytes in the lakes lateral to a tropical river (Paranapanema river, São Paulo, Brazil). Acta Limnol Bras 22: 122-132. 
DOGIEL VA. 1958. Ecology of the parasites of freshwater fishes. In: Dogiel VA et al. (Eds), Parasitology of fishes. Edinburgh: Oliver and Boyd, p. 1-47.

EIRAS JC, TAKEMOTO RM AND PAVANELLI GC. 2006. Métodos de estudo e técnicas laboratoriais em parasitologia de peixes. Maringá: EDUEM, 199 p.

FELTRAN RB, JÚNIOR OM, PINESE JF AND TAKEMOTO RM. 2004. Prevalência, abundância, intensidade e amplitude de infecção de nematóides intestinais em Leporinus friderici (Bloch, 1794) e L. obtusidens (Valenciennes, 1836) (Pisces, Anostomidae), na represa de Nova Ponte (Perdizes, MG). Rev Bras Zoocienc 6: 169179.

FORSTIE M AND HOLLOWAY JR HL. 1984. Parasites of fish from the James and Sheyenne Rivers, Jamestown Reservoir complex, and Lake Ashtabula in North Dakota. Prairie Nat 16: 11-20.

GARCIA-MELLADO A, OLIVA-PATERNA FJ, CARVALHO ED AND TORRALVA M. 2002. Catch and selectivity parameters of the anostomid fish Schizodon nasutus using gillnets in the Jurumirim reservoir (São Paulo, Brazil). Ital J Zool 69: 333-338.

GARDNER C, COGHLAN JR SM, ZYDLEWSKI J AND SAUNDERS R. 2013. Distribution and abundance of stream fishes in relation to barriers: implications for monitoring stream recovery after barrier removal. River Res Appl 29: 65-78.

GRAÇA WJ AND PAVANELLI CS. 2007. Peixes da planície de inundação do Alto rio Paraná e áreas adjacentes. Maringá: EDUEM, 241 p.

GUIDELLI G, TAVECHIO WLG, TAKEMOTO RM AND PAVANELLI GC. 2006. Fauna parasitária de Leporinus lacustris e Leporinus friderici (Characiformes, Anostomidae) da planície de inundação do alto rio Paraná, Brasil. Acta Sci Biol Sci 28: 281-290.

GUMIERO B AND SALMOIRAGHI G. 1998. Influence of an impoundment on benthic macroinvertebrate habitat utilization. Verh Internat Verein Limnol 26: 2063-2069.

HAMMER O, HARPER DAT AND RYAN PD. 2001. PAST: Paleontological Statistics software package for education and data analysis. Palaeontol Electro 4: 1-9.

HENRY R, NOGUEIRA MG, POMPÊO MLM AND MOSCHINI-CARLOS V. 2006. Annual and short-term variability in primary productivity by phytoplankton and correlated abiotic factores in the Jurumirim reservoir (São Paulo, Brazil). Braz J Biol 66: 239-261.

HENRY R, NUNES MA, MITSUKA PM, LIMA N AND CASANOVA SMC. 1998. Variação espacial e temporal da produtividade primária pelo fitoplâncton na represa de Jurumirim (Rio Paranapanema, SP). Braz J Biol 58: 571590 .
HITT NP, EYLER S, JOHN EB AND WOFFORD JEB. 2012. Dam removal increases american eel abundance in distant headwater streams. Trans Am Fish Soc 141: 1171-1179.

HOGG R, COGHLAN JR SM AND ZYDLEWSKI J. 2013. Anadromous sea lampreys recolonize a marine coastal river tributary after dam removal. Trans Am Fish Soc 142: 1381-1394.

HOLLOWAY HL AND HAGSTROM NT. 1981. Comparison of four North Dakota impoundments and factors affecting the development of impoundment parasitofauna. Prairie Nat 13: 85-93.

JORCIN A AND NOGUEIRA MG. 2008. Benthic macroinvertebrates in the Paranapanema reservoir cascade (southeast Brazil). Braz J Biol 68: 1013-1024.

KADLEC D, ŠIMKOVÁ A, JARKOVSKÝ J AND GELNAR M. 2003. Parasite communities of freshwater fish under flood condition. Parasitol Res 89: 272-283.

KARLING LC, ISAAC A, AFFONSO IP, TAKEMOTO RM AND PAVANELLI GC. 2012. The impact of a dam on the helminth fauna and health of a neotropical fish species Salminus brasiliensis (Cuvier 1816) from the upper Paraná River, Brazil. J Helminthol 87: 245-251.

KOHNA, MORAVEC F, COHEN SC, CANZI C, TAKEMOTO RM AND FERNANDES BMM. 2011. Helminths of freshwater fishes in the reservoir of the Hydroelectric Power Station of Itaipu, Paraná, Brazil. Check List 7: 681690.

KRASNOV BR, FORTUNA MA, MOUILLOT D, KHOKHLOVA IS, SHENBROT GI AND POULIN R. 2012. Phylogenetic signal in module composition and species connectivity in compartmentalized host-parasite networks. Am Nat 179: 501-511.

KURCHEVSKI G AND CARVALHO ED. 2014. Os peixes da represa de Jurumirim: revisão temporal de estudos independentes. In: Henry R (Ed), Represa de Jurumirim: ecologia, modelagem e aspectos sociais. $1^{\mathrm{a}}$ ed., Ribeirão Preto: Holos, p. 325-342.

LAFFERTY KD. 1997. Environmental parasitology: What can parasites tell us about human impacts on the environment? Parasitol Today 13: 251-255.

LAFFERTY KD AND KURIS AM. 1999. How environmental stress affects the impact of parasites. Limnol Oceanogr 44: 925-931.

LEES AC, PERES CA, FEARNSIDE PM, SCHNEIDER M AND ZUANON JAS. 2016. Hydropower and the future of Amazonian biodiversity. Biodivers Conserv 25: 451-466.

MACKIE GL, MORTON WB AND FERGUSON MS. 1983. Fish parasitism in a new impoundment and differences upstream and downstream. Hydrobiologia 99: 197-205.

MAGURRAN AE. 2004. Measuring biological diversity. Oxford: Blackwell Science, $256 \mathrm{p}$. 
MCCUNE B AND MEFFORD MJ. 1999. PC-ORD. Multivariate analysis of ecological data. Version 4.0. Gleneden Beach, Oregon, MjM Software Design.

MCKINNEY ML. 2006. Urbanization as a major cause of biotic homogenization. Biol Cons 127: 247-260.

MCKINNEY ML AND LOCKWOOD JL. 1999. Biotic homogenization: a few winners replacing many losers in the next mass extinction. Trends Ecol Evol 14: 450-453.

MILLENNIUM ECOSYSTEM ASSESSMENT. 2005. Ecosystems and Human Well-being: Synthesis. Washington, DC: Island Press, $137 \mathrm{p}$.

MITSUKA PM AND HENRY R. 2002. The fate of copepod populations in the Paranapanema River (São Paulo, Brazil), downstream from the Jurumirim Dam. Braz Arch Biol Technol 45: 479-490.

MORAVEC F. 1998. Nematodes of freshwater fishes of the Neotropical region. Czech Republic: Academia Praha, 464 p.

MORLEY NJ. 2007. Anthropogenic effects of reservoir construction on the parasite fauna of aquatic wildlife. EcoHealth 4: 374-383.

MOSCHINI-CARLOS V, HENRY R AND POMPÊO MLM. 2000. Seasonal variation of biomass and productivity of the periphytic community on artificial substrata in the Jurumirim Reservoir (São Paulo, Brazil). Hydrobiol 434: 35-40.

NILSSON C, REIDY CA, DYNESIUS M AND REVENGA C. 2005. Fragmentation and flow regulation of the world's large river systems. Science 308: 405-408.

NOGUEIRA MG, HENRY R AND MARICATTO FE. 1999. Spatial and temporal heterogeneity in the Jurumirim Reservoir, São Paulo, Brazil. Lake Reserv Manage 4: 107120.

NOGUEIRA MG, JORCIN A, VIANNA NC AND BRITTO YCT. 2006. Reservatórios em Cascata e os Efeitos na Limnologia e Organização das Comunidades Bióticas (Fitoplâncton, Zooplâncton e Zoobentos) - Um Estudo de Caso no Rio Paranapanema (SP/PR). In: Nogueira MG (Ed), Ecologia de Reservatórios: Impactos Potenciais, Ações de Manejo e Sistemas em Cascata. $2^{a}$ ed., São Carlos: Rima, p. 83-126.

O'CONNOR JE, DUDA JJ AND GRANT GE. 2015. 1000 dams down and counting. Science 348: 496-497.

OLDEN JD, POFF NL, DOUGLAS MR, DOUGLAS ME AND FAUSCH KD. 2004. Ecological and evolutionary consequences of biotic homogenization. Trends Ecol Evol 19: $18-24$

OLDEN JD AND ROONEY TP. 2006. On defining and quantifying biotic homogenization. Global Ecol Biogeogr 15: 113-120.

OLIVA ME AND BALLÓN I. 2002. Metazoan parasites of the Chilean hake Merluccius gayi gayi as a tool for stock discrimination. Fish Res 56: 313-320.

POFF NL, OLDEN JD, MERRITT D AND PEPIN D. 2007. Homogenization of regional river dynamics by dams and global biodiversity implications. Proc Natl Acad Sci 104: $5732-5737$.

POULIN R. 2003. The decay of similarity with geographical distance in parasite communities of vertebrate hosts. J Biogeogr 30: 1609-1615.

POULIN R AND MORAND S. 1999. Geographical distances and the similarity among parasite communities of conspecific host population. Parasitology 119: 369-374.

RAHEL FJ. 2002. Homogenization of freshwater faunas. Annu Rev Ecol Evol Syst 33: 291-315.

RAHEL FJ. 2007. Biogeographic barriers, connectivity and homogenization of freshwater faunas: it's a small world after all. Fresh Biol 52: 696-710.

RAHEL FJ. 2010. Homogenization, differentiation, and the widespread alteration of fish faunas. Am Fish Soc Symp 73: 311-326.

SARTORI LP, NOGUEIRA MG, HENRY R AND MORETTO EM. 2009. Zooplankton fluctuations in Jurumirim Reservoir (São Paulo, Brazil): a three-year study. Braz J Biol 69: 1-18.

SCOTT MC. 2006. Winners and losers among stream fishes in relation to land use legacies and urban development in the southeastern US. Biol Cons 127: 301-309.

STATSOFT INC. 2005. Statistica (data analysis software system), version 7.1.

THATCHER VE. 2006. Amazon fish parasites. Sofia, Bulgaria, Pensoft Publishers, 508 p.

WHITTAKER RH. 1960. Vegetation of the Siskiyou Mountains, Oregon and California. Ecol Monogr 30: 279338.

WILSON JB. 1990. Mechanisms of species coexistence: twelve explanations for Hutchinson's "paradox of the plankton": evidence from New Zealand plant communities. N Z J Ecol 13: 17-42.

ZAR JH. 2010. Biostatistical analysis. New Jersey, PrenticeHall, Inc., 663 p. 